\title{
Noble Systems Inc.: Inside The Mind Of An Entrepreneur
}

Paul Schumann, Minnesota State University-Mankato, USA Timothy Scott, Minnesota State University-Mankato, USA Jon Kalinowski, Minnesota State University-Mankato, USA John Kaliski, Minnesota State University-Mankato, USA

Claudia Pragman, Minnesota State University-Mankato, USA

\begin{abstract}
This case illustrates the challenges faced by typical start-up businesses. The company has never earned a profit. Losses are being covered by cash infusions from angel investors. While significant business opportunities are present, the company doesn't have the money to pursue them all. Essentially, the case involves problems of growth, vision, potential, and management. The problems illustrated in the case can be analyzed using theories and approaches such as: SWOT analysis, financial analysis, business valuation, strategic human resource management, and strategic marketing/management. The case and Instructor's Manual were written for undergraduate or MBA courses in strategic management. They can also be used in an entrepreneurship course if the instructor wishes to have a case that illustrates the strategic challenges associated with the decision whether to stay small and within the abilities of the founders, or to grow beyond their capabilities.
\end{abstract}

Keywords: Start-Up Business; Entrepreneurship; SWOT Analysis; Business Valuation; Growth, Vision

\section{INTRODUCTION}

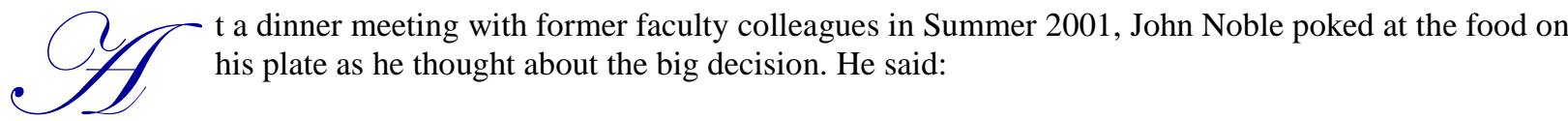

It seems like you would understand early on where you wanted to go, but it wasn't until around 2000 that eventually we sat down and said: 'What do we want to be? Do we want to be a regional player? Do we want to be a niche player? Do we want to compete with the big boys? Do we want to get big or go home?' We looked around and said: 'We think we could make it as a niche player. Do we want to try for the homerun here? Do we start to get our financing in order and swing for the fences?'

John reflected on his personal goals that got him into this situation and on the opportunity to sell the business that he had already let pass:

I personally never really wanted to become rich. I wanted to become wealthy enough that I could walk away from technology and the rest of the world and build things - work with my hands and things like that. We were recently offered in the low tens of millions for the company. The other board members and I talked about it and we all decided: The company is worth $\$ 10$ to $\$ 12$ million right now. We are going great guns. We are getting great customers. We think that if we keep it up for another year or two, we might be able to throw an extra digit on to that evaluation so that $\$ 10$ to $\$ 12$ million will become $\$ 100$ to $\$ 120$ million.

\section{THE FOUNDING OF NOBLE SYSTEMS}

John Noble was an MIS professor in a medium-sized Midwestern public university. In 1995, John had been teaching an introduction to MIS course for three years. He said he was frustrated and bored by the housekeeping 
tasks of teaching, such as passing out syllabi and assignments, grading assignments and exams, and entering students' scores into the gradebook. John hated wasting his time on things that he felt could be better done by the computer.

In 1995, the World Wide Web was new. At that time, there were no commercially available eLearning systems that would automate some of the housekeeping tasks of teaching. John began developing a Web-based eLearning system that would reduce his frustrations with teaching by automating these tasks. As he developed the system for his own use, other professors expressed interest in using it. The first version was ready for his personal use in Spring 1995 and for general use in Fall 1996. As other professors adopted his eLearning system, John realized that it had commercial potential.

Noble Systems Inc. was incorporated in December 1996 as an S-Corporation, with a 50/50 equity split by John Noble and Jack O'Brien. Jack O'Brien was the fundraiser for one of the colleges at the university. Since John and Jack worked at a university, they both understood the higher education market and the potential for new information technologies to revolutionize learning. While John focused mostly on developing the product, Jack focused mostly on developing the company. Jack started working for Noble Systems full-time in April 1997. The first round of investments by angel investors occurred in early 1997. As additional investors joined the company, John and Jack watched their equity stakes dramatically erode.

\section{THE EARLY SALES}

The Noble eLearning system was commercially launched in the college market in May 1997 at an academic conference. It was marketed only to colleges at that time. The company hired its first 3 employees in Summer 1997 and achieved a series of small sales during Fall 1997. As 1998 unfolded, Noble Systems continued to hire technical and support staff and began to develop sales leads at several large colleges.

At the dinner meeting, thinking back to those early days, John said:

There is always a sequence of events that have come together - a series of proofs of concept - for any small business to succeed. The first one for us was the first small account. What matters more, however, is the first decentsized adoption. That larger adoption tells you a lot about the quality of the product, the ability to provide service to customers, and the ability to handle situations when they occur. It is proof across the whole spectrum of the company - not just did the techno widget do what it was supposed to do - but did all the rest of the infrastructure in back of it also work: people and networks and security and a million other things.

By mid 1998, Noble Systems succeeded in selling its eLearning system to several colleges. As one of the original eLearning systems in the marketplace, Noble helped to define the product and the market along with many of the other small boutique companies that started around the same time. Some of them focused on selling services to create educational content using a services model where the product was customized to fit the customer's needs. Others, including Noble, focused on selling stand-alone software using a product model where the same product was sold to diverse customers. As was typical of new industries, a period of industry consolidation quickly followed where large amounts of venture capital were raised, there were mergers and acquisitions, and some companies failed. Out of this consolidation, several large players emerged: Blackboard, WebCT, eCollege, and Noble Systems.

The early products in the industry were characterized by lots of bugs, poor scalability, user-interface problems, and a lack of service and support. Poor scalability meant that the product could only support a limited number of users at one time.

\section{THE PRICING AND MARKETING STRATEGIES} and 1999:

John felt that the Noble eLearning system was superior to the competition, even in the early days of 1998

Obviously you are talking to the most biased person on the face of the earth since I built it, but in terms of functionality our product was much richer than anyone else's in the market. With every review that we ever got, it 
was never an issue of product functionality, scalability, security - anything to do with the product truly was always solid. The product has always been one of our great strengths. In terms of price? Our pricing strategy was not to be the lowest priced eLearning product. Instead, we set our price at a middle price point. The idea was to offer a great product at a mid-tier price. While our strategy was not to have the lowest price, we did strive to have the lowest total cost of ownership among the eLearning platforms. Total cost of ownership includes the initial purchase price, the cost of training and integration services, ongoing maintenance and upgrade costs, eLearning service costs, etc.

The belief that Noble Systems had the lowest total cost of ownership was confirmed by potential customers' evaluations. One of the very large colleges that was an early adopter of the Noble eLearning system completed a thorough comparison of Noble's product versus its competitors' products, including Blackboard and WebCT, and concluded that Noble had the lowest total cost of ownership. In describing this evaluation that resulted in the first big sale, John said:

That was why that win was so sweet. They had evaluated the other competitors and they had been really disappointed in the performance, scalability, and flexibility in a hundred things. They had done an ROI with all the academic players and Noble was square at the top of their document. So product-wise, cost-wise, service-wise, the total cost of ownership-wise, they evaluated Noble as best.

Once Noble landed its first really big customer in Summer 1999, the pace quickened. John said:

So then here's what occurs ... lots of activity to support this new big fish that we had landed. But then that big fish becomes a champion for you to go after other big fish. That customer helped to generate lots of great sales leads for us. Of course we didn't land all of them, but our exposure in the marketplace increased dramatically.

Once Noble Systems made a series of small sales and the one really big sale, it needed additional staff. Noble hired a Vice-President of Sales in Summer 2000. It also succeeded in making a second big sale in Summer 2000 .

John summarized Noble's marketing strategy:

Higher ed was our bread and butter. By Summer of 2000, we had started to investigate corporate training as an outlet for our product; we even had our first few small-scale corporate sales, but higher education was still where we made most of our money and where we focused most of our energies.

\section{THE ACADEMIC SALES CYCLE}

To sell to the academic target market, Noble Systems focused on selling directly to the senior levels within the higher education institutions; the goal in doing so was to shorten the sales cycle slightly and help with sale closure rates - directors and administrators were the ones who controlled the budgets and spent the money, not professors and staff members. In describing the marketing efforts, John said:

We couldn't afford to advertise. In the academic space, lots would happen at educational conferences. We would go to these conferences, setup a small booth, and demonstrate our product. Conferences were enormously expensive our last conference cost us about $\$ 60,000$ - but we got a contract out of every conference we attended. There were several that we would go to every year. We would typically have a small to medium size booth. They were real meat markets. All sorts of our competition attended. The other little fish like us were there; also the really big players like the Microsofts and the IBMs and the Apples also were always there. The big players were impressive; their booths were incredible - probably a half-million dollars or more for a few days.

Those conferences really wind up being the start of the sales cycle. You get a business card, you have a contact, you have a conversation, and you do some really off-the-cuff high level needs assessment. The people with the prettiest faces and the best personalities and the strongest handshakes are there. 
At the start of the sales cycle there is kind of a bi-directional qualifying that goes on. The customer is sniffing you out trying to understand what kinds of things you do; you are also trying to understand what the customer needs. Assuming there is some intersection, then you know how to direct the sale towards their needs.

Knowing what the customer wants is essential. Without that you are blind in the sales cycle. With that knowledge we can tailor the demo to customer needs. We would mock up what their environment would look like with their logos, their colors, their names, and their whole shebang.

Then typically there is a handing off during the sales cycle, with eventually Jack O'Brien closing the sale. The process of closing the sale and getting a signed sales contract in the higher education market takes a horrifically long time. Because most of the sales Jack is pitching are at an institution-wide level, the sales process touches many groups within the university: faculty, computing services, finance, senior management, etc. Each stage takes ungodly long and typically the communication among the university groups is very poor. The decision process within and between each group is usually poorly defined. This is a nightmare situation for a vendor trying to sell into - it seems like no one in a university has the power to make the final purchase decision.

\section{ORGANIZATIONAL CHALLENGES CREATED BY SUCCESS IN SALES}

As Noble's managers continued to work on sales prospects, they also had to continue to develop the product and to manage corporate operations as the company grew. Furthermore, as the Internet grew in popularity, the pace of technological change quickened. At the dinner meeting, John Noble explained:

A brief calendar of events. Today, we all kind of look at the Web as a stable, predictable thing. The release of Internet Explorer you are using has been the same release for a couple years now. It doesn't crash very often. Okay - that's great. When we started Noble, not only were we a start-up company with people that didn't know beans about business, eLearning was a start-up industry. In fact, the term eLearning didn't exist at the time and the Web was brand-spanking new. We started the company in 1996 and Netscape Version 1.0 (the first Web browser) had just come out in 1995. New major releases of everything were coming out hourly. It was just a huge chaotic nightmarish kind of an environment to live through because nobody knew what anybody was doing. So, at that point we would just release stuff as quick as we could possibly release it. Did we test sufficiently? Absolutely $100 \%$ no. Did we release crap? Absolutely 100\% yes. Did everyone else? Absolutely yes, because speed was the only thing that mattered at that time. It was psychotic.

Now fast forward a little bit. Things were starting to stabilize. You could do that kind of cowboy, shooting from the hip sort of business when you have a small number of small sales. However, when you are starting to have bigger players invest bigger money and invest strategic importance to this thing, being a cowboy is exactly the wrong thing. The needs of the operation changed markedly. The operation went from 'Just slap the stuff out as quick as you possibly can and we will fix it when it breaks later,' to customers saying 'I want high quality, I want process documents, I want predictability, I want release notes, I want a fixed schedule, I want to know when minor releases are coming out, I want to know when major releases are coming out, I want to know what functionality is going to be in those, I want validated performance measurements, I want to know which bugs are going to be fixed, I want to know are there going to be any interface shifts.' What the customers want is predictability and reliability. They want to know what is going to be released and when. They want to know it's reasonably bug free. They want to know and be able to predict all of this stuff. We came to look at our customers as partners in developing the product. Yes, Noble was writing the code, but it is a bad thing if we come out with something that blows all of our customers' users away.

John pointed out that by Summer 2000, approximately 35-40 colleges had adopted the Noble eLearning system. Two of these customers were among the largest college systems in the United States. John explained that in this time period, he was the technical guru who was primarily responsible for developing the product while Jack O'Brien was primarily responsible for sales and for raising money from investors. The employees were also split into two groups: the technical and the non-technical employees, with the tech employees reporting to John and the non-tech employees reporting to Jack. John turned to Jack and said "What do you have to add to my explanation of what was going on?" 


\section{SALES GROWTH NECESSITATES FORMALIZED PROCEDURES}

Jack O'Brien explained that as Noble Systems added customers, it needed to add customer support resources. Jack said: "We also needed someone to bridge the two sides of the business, tech and non-tech." Noble Systems hired Carol Jackson as Vice-President of Customer Care in December 2000. John Noble explained:

Frankly, in terms of operations early on, we were crap. We were terrible and I was responsible for that: My predilection is to shoot first and ask questions later. I can build stuff very quickly. But that's not always the right thing to do. It hurts predictability. It took us a long time to put the operational infrastructure together to get that predictability and that wasn't me that fixed that at all, that was Carol. She's the one that put a bridle on me and said, 'You are never talking to a customer again. It will all come through me.' She was dead on the money. She was exactly right.

Before Carol was hired by Noble she had worked at several small to medium size software and technology businesses. She had an established history of 'hunting' and 'farming' accounts. She was good at generating new leads and walking the new customer through the start-up process. But the bigger thing to Noble was that Carol excelled at making the existing customers very happy and providing an unending stream of up-sale possibilities. Her project and people management skills were tremendous.

The first thing was she ensured that for each customer there was a single point of contact. It provided one name and face that the customer knew and that person had responsibility for that account. That helped. It seems like such a trivial little thing, and it is, but that account manager has final responsibility and should have complete knowledge of that account. So that is the first thing that she did.

The second thing that she did was to say 'We are going to come up with a very formalized schedule. We are going to develop a measure of bug severities. Short of the most severe bug, we are never going to touch code in a live environment again. You will always touch code in a development environment and then roll out the new version of the software in planned releases.' Carol formalized the release schedule. She formalized the documentation release notes. She formalized the documentation of the whole process to the customer. She also formalized the process of doing an install.

I am not a formalized person. Furthermore, because I built it, I had good knowledge of the whole system and I knew what I could do and when I could do it. Well that is wonderful, but it doesn't scale very well. If you have one person in the universe that knows how to do something and he is hit by a bus, you are screwed. So what Carol did was to codify the process.

As a result of Carol taking responsibility for operations, and as a result of hiring software developers to handle more of the software writing, John's role changed:

The thing I enjoyed the most was being the architect of the product. That's the thing for which I was best suited. While I didn't do as much software coding, I still wrote some code. I managed all of the tech staff who did most of the coding. All of our internal technology was my responsibility.

John also was responsible for determining how the customer's technology would interface with Noble's product and for evaluating new releases of competing products. He continued to be responsible for senior-level activities such as reading marketing reports, attending board meetings, and strategic planning.

To summarize his new role, John said: "If it had to do with the product, if it had to do with evaluating potential partners, if it had to do with any technology, it was my responsibility. If it was a customer-related or daily operational-related thing, it was Carol's responsibility. If it had to do with sales or dealing with investors or potential investors, it was Jack's responsibility." Jack O’Brien explained it this way: "I'd sell it, John would implement it, and Carol would handle customer relations."

Despite the fact that it was a slow and frustrating process to sell to the higher education market, with a sales process that tended to be long and unpredictable with many false starts, Noble Systems in early 2001 had 35-40 
university accounts and had achieved several large sales to large college systems. As a result of the success in sales, Noble Systems continued to grow and add employees. In this time period, Noble had a total of 12-15 employees. Of these, 3 or 4 were software developers and most of the rest were in sales and marketing. John Noble was responsible for hiring and firing technical employees, Carol Jackson was responsible for customer support and project management employees, and Jack O'Brien was responsible for sales employees. John and Jack as founders and partners were the senior managers with responsibility for strategic management. As the day-to-day operations person, Carol was not responsible for strategic management.

\section{HUMAN RESOURCES}

Jack O'Brien explained that Noble had hired a consultant to write an employee handbook because some universities were demanding to see the handbook before they would deal with Noble Systems. Although Noble Systems had the employee handbook, Jack noted that they were still playing fast and loose with their HR; they were learning HR as they went along. John Noble said: "Human resources were very important from a cost perspective about $80 \%$ of our costs were labor costs. But we had HR on autopilot and senior management did not put much thought into who should be responsible for managing HR and how." This was because staffing was done through personal contacts. John would hire his best and most promising MIS students for the technical work, and Jack would hire sales and marketing personnel who had experience from working for other local software companies. Employees were more like friends and family, so a formal HR system did not seem necessary. As a consequence, during this time period no formal employee performance reviews were done. Similarly, while employees were hired at market pay rates or slightly better, pay increases were haphazardly done and employees stayed at the same pay rate for long periods of time. However, Noble Systems did make use of stock options. John explained:

We have good relationships with our employees. Our employees are loyal and hard-working - they work long hours, nights, weekends, whatever it takes. We looked at this as a family, and we had said it a million times in a million different meetings, and we believed it as senior management, that if the company won, everybody should win.

Jack O'Brien agreed: "Our employees are very loyal to the company. They'll work nights and weekends. They'll stay in cheap hotels when traveling on company business. Everyone believes in John and me.”

\section{THE EDUCATION COMPETITIVE LANDSCAPE}

At the dinner meeting, John said:

At the present time in mid-2001, more than a quarter of a million students are using the Noble eLearning system. A key reason for our success is having a superior product and happy customers. The satisfied customers result in good references, which lead to more sales.

While Noble Systems is enjoying success in the higher education eLearning market, the competition, particularly Blackboard and WebCT, is having even greater success. Blackboard and WebCT are getting their act together from a product standpoint and it is becoming a horse race. We are stronger in terms of product, but they are developing better market reach. We see their ads in all sorts of journals and they always have very large booths at the conferences.

The emerging threat of Blackboard and WebCT was due in large part to their financing and corporate parnerships. Noble Systems had never used institutional investors; instead, Noble was financed mostly by private or angel investors. An angel investor is an affluent individual who provides capital for a business start-up, usually in exchange for convertible debt or ownership equity. Noble Systems was still too small for an IPO. While it was primiarily Jack O'Brien's responsibility for finding and closing deals with angel investors, all of senior management had to spend substantial amounts of time raising capital from these investors. Jack O'Brien explained:

We've always been able to raise enough money from investors. We're selling investors on our vision of the future. We're selling projections of the future during a tech gold rush. Potential investors are seeing people getting rich on 
technology and they want to get in on the next big thing in tech. If an investor puts $\$ 100,000$ into a mutual fund, that isn't sexy. But if an investor puts $\$ 100,000$ into a start-up tech company, that's sexy - they have a good story to tell their friends on the golf course. Of course, we don't have enough money to do everything all at once. We still need to make some difficult choices about whether to spend money on technology or on marketing. Do we spend money on a marketing brochure or on a server? And we did make some mistakes early on in underestimating just how much money we'd need to raise. But we were still able to produce great results.

John Noble added:

The ability to craft a coherent marketing message to potential investors is critical. In addition to looking at the potential of the product and company, potential investors also look seriously at Noble's senior managers and their ability to deliver on their vision. All the players in the industry at this time are cash flow negative. Noble does not have the benefit of large venture capital rounds. Because of this, Noble needs to be continually infused with angel investment. Since typical angel investments are small $(\$ 50,000-\$ 250,000)$, the ability to excite a stream of investors with the possibilities that eLearning offers and the potential of Noble is of paramount importance. Without this activity the rest is meaningless.

Noble Systems needed hundreds of thousands of dollars per year from angel investors, with an average investment of $\$ 100,000-\$ 150,000$ per investor. John continued:

The competition has begun large, expensive marketing campaigns. The expense of conferences is skyrocketing along with the costs of direct marketing to professors. While some of this is being funded through cash flows, much of it has to be done through cash infusions. It's not only that our competitors have deeper pockets, but they also have more recognizable pockets. What I mean here is that it is cool to have \$10 million to work with to fund operations, but it is infinitely better to have $\$ 10$ million from Microsoft or some other big ticket partner to fund operations. The ability of competitors to put 'Partner with Microsoft' on their website is huge; the customers would look at that and say, 'Oh, well, if Microsoft thinks these guys are okay, then they are probably okay.' We don't have that.

As dessert was arriving, John sighed and said:

In order for you to understand the decision we are contemplating, you need to walk in my shoes for a little while and understand what the eLearning market is like right now. eLearning as an industry is experiencing dramatic growth. It has reached general acceptance both within the higher education and corporate training markets. For the past few years, the eLearning market as a whole has almost doubled annually. It's been that crazy. The market has adopted the mantra that we in eLearning have been preaching for years: Just-In-Time Learning. If eLearning is done well, it facilitates the learning when the learner needs it the most, at the place and time he needs it, at an appropriate pace for his current lifestyle, and at a cost that is more palatable for everyone.

From the bigger picture, there are a lot of societal factors driving this growth. First, the technology has finally matured enough for it to be reliable and robust. Next, there are huge pressures to reduce costs in our knowledge based economy; everyone wants it faster and cheaper. There is a shortage of skilled workers everywhere and many industries require that their professionals receive annual certification training. As a consequence, companies are setting up corporate universities. Companies are competing in a $24 / 7$ global economy that requires them to reduce their time to market, control their costs, and ensure consistency of training across huge, geographically distributed employee and customer bases. eLearning powers all of these drivers.

The eLearning industry is comprised of companies either focusing on content development, content delivery, or learning services. While most of the players started in one of these sectors, many are looking to expand their offerings into all three either by building it themselves or through acquisition. Currently, we see a lot of M\&A happening. The goal here is simple: eLearning companies are trying to develop a "one stop shop" approach that would provide for all of the customer's eLearning needs. Successful players must offer (or partner to offer) learning systems, consulting services, content development and repurposing of existing content, and deployment and integration facilities. This expertise flows throughout the eLearning company's approach to the market. In addition to offering integrated solutions to customer's needs, products must be competitively priced through subscription or product licensing models. 
Of course, none of this comes cheap. Success in the eLearning market will require many small firms to acquire the necessary capital for growth. To generate that kind of capital, they will need to show that they have the capabilities to respond to an increasingly sophisticated customer base. Companies like ours must consistently meet the demand for ever increasing functionality and the usage requirements of a daunting variety of learning environments. Beyond pricing, we need to demonstrate a strong Return on Investment for our products. The whole eLearning industry needs products that can be rapidly deployed. Long, complex, risky eLearning implementations are mostly a thing of the past. Also, the implementations must easily integrate with the customer's existing computing environment. Since eLearning has become a strategic function within many organizations, companies like ours must ensure consistent, timely, and professional support for their customers.

Finally we must provide a robust set of tools and training on those tools that will allow the customer's content developers to easily maintain and to create their own proprietary learning materials.

\section{COMPETITORS GAIN TRACTION FASTER}

The competition also is partnering with college textbook publishers. These partnerships result in the textbook publishers providing professors with course content already in Blackboard or WebCT, which frees the professors who use Blackboard or WebCT from having to do the work of loading course content into the eLearning system. John said:

The competition is forming strategic partnerships with large publishing, software, and consulting companies. These partnerships can become critical because they can be leveraged to extend the reach of the small, startup firms. When publishers begin tailoring their content to WebCT and Blackboard, they make the product easy for faculty to use and give faculty a reason to choose a certain publisher's textbook. These partnerships not only provide a known cash flow, but more importantly they imply a much needed validation of the startup's stability and quality. Such external validation is key because it answers company-level concerns expressed by customers considering making large, enterprise-level purchases. We lack these partnerships.

Jack O'Brien pointed out that he (on behalf of Noble Systems) approached one major textbook publisher and made a presentation to try to begin developing a partnership. However, the response from the publisher was to "Have your investment banker call our investment banker." Noble Systems did not have an investment banker at the time. WebCT had an investment banker and so was able to close the deal. The publisher's decision about which eLearning company to have as a partner was thus driven by financial and investment factors, not the product or the managers.

Jack O'Brien went on to explain:

Another challenge is that we're located in a small city of around 50,000 people in the Midwest while most of the tech action is in California. While we've been successful at hiring techies from the university located in town, it's not quite the same as if we were located in the heart of the tech action where almost everyone on every street is a techie. Furthermore, our location increases our travel costs. When we have to travel, we tend to stay in cheap hotels and stay over a Saturday night to get the cheap airfares.

Furthermore, the competitors were adding new employees faster than Noble. Noble had fewer than 20 employees while each of the competitors had 200 or more, which allowed them to more easily have specialized employees.

John Noble said: "I fear that they can beat us. We can win the battles and we can have a better product, but we worry that they could out-spend us, out-market us, and out-finance us." The concern was that if the competition became elephants while Noble remained a mouse that the elephants would step on the mouse. The senior management of Noble therefore began to explore target markets other than higher education. 


\section{THE POTENTIAL FOR OTHER TARGET MARKETS}

Noble had a small handful of corporate accounts that were using the Noble eLearning system to train their employees, but corporate training was not Noble's main focus. John and Jack believed that the corporate market could be very attractive. There were lots of initiatives to incorporate the Internet into daily life. Just as the emerging business-to-business companies were developing Web-based products to revolutionize purchasing, so too the eLearning companies were developing Web-based products to revolutionize education and training. A strong part of Jack O'Brien's pitch to potential angel investors was the vision and potential for the Internet and eLearning to change how people educate themselves by facilitating life-long learning. John and Jack believed that eLearning could be bigger than e-mail by revolutionizing teaching and training. Thus, the potential was not only to revolutionize college education, but also to revolutionize how companies provided training. They summarized the vision that they were selling to potential investors by saying: "Life-long education any place, any time."

The corporate training niche actually consisted of several potential target markets such as insurance, real estate, fast food, and medical. John and Jack referred to each of these possible markets as "verticals." At the dinner meeting in Summer 2001, John said:

The best of these verticals is the insurance vertical. This is not a small vertical in that the industry requires every independent insurance agent to have continuing education training every single year. You're talking about 300,000 insurance agents in one US insurance corporation alone. Add onto that Canada and Europe, and you have an opportunity that is bigger than any university by orders of magnitude, and they have lots of dollars. So the insurance vertical is a big opportunity.

John and Jack said they were familiar with the insurance vertical because one of their salespersons had extensive personal knowledge of and contacts in the insurance industry. As a result, Noble managers decided to test a large market outside of higher education by using their insurance industry contacts. In February 2001, a major insurance corporation selected Noble for its virtual university for its 300,000 member agents. John and Jack felt this was a huge success for Noble because it illustrated the sales potential of at least the insurance vertical. They thought that if one sale could bring as many as 300,000 users, then it wouldn't take that many more big sales to make Noble one of the major players in the eLearning overall market.

John pointed out that the financial impact of this big sale depended on how quickly the insurance corporation implemented the Noble eLearning system. Noble's potential revenues from this sale was a function of four things: (1) the number of member agents that used Noble's eLearning system for training, which was potentially as high as 300,000; (2) the number of credits taken per employee, which averaged 15 credits per employee per year; (3) the price per credit, which typically was between $\$ 15$ and $\$ 50$; and (4) Noble's share of the gross revenue, which ranged between $20 \%$ and $30 \%$.

John said Noble's actual revenue stream from this sale, however, was likely to be lower than the potential revenues because not all of the training would be immediately converted to Noble's system. John said that this was due to four factors: (1) It took time to develop learning content and move it into the Noble system. (2) It took time to change people's habits: if instructors were used to providing the training in other ways, they were reluctant to learn Noble's system and to switch. (3) The Noble system worked best with fast Internet connections while many of the insurance agencies were still using slow dial-up Internet connections. (4) It took time to gain acceptance for any one solution because different factions within the insurance corporation wanted to choose their own system.

John and Jack began to explore other verticals based on personal contacts. For example, they saw a large real estate company as a potential customer in the real estate vertical and a large fast food company as a potential customer in the fast food vertical. John said: "If you think about a fast food company, the employee turnover rate is phenomenal. Every one of these employees needs to be trained on how to make the sandwiches and run the point-ofsales systems and all this other stuff. A huge amount of training is needed." 


\section{ADVANTAGES AND DISADVANTAGES OF NEW MARKETS}

John and Jack identified some professions with extensive amounts of continuing education. Table 1 shows the annual expenditures of continuing education in 10 professions. John said:

So we are looking at these other verticals. We are thinking about growing to the next step. We are successful in that we have a successful product with happy customers. We are a successful company, but the threats are real threats. What's happening is the horserace is becoming a dollar-centric horse race and it is becoming harder to compete in the higher education market. Selling to the higher education market is a pain in the neck for everybody. So we are looking at these other verticals thinking that there is much more money in the other verticals than in higher education and the other verticals are easier to sell into.

The verticals other than higher education are attractive for a number of reasons. The sales cycle outside of higher education is shorter because you can reach an identifiable decision-maker. It isn't an easy slam dunk on the other side, but decision-making roles are better defined in the corporate world. For example, most companies have someone in charge of corporate training who has a budget. If we convince that person, he or she then becomes our champion in navigating the rest of the corporate decision-making process.

Furthermore, we have a good contact inside the insurance industry and we've already made one big sale in the insurance industry. In addition, Carol is excellent at listening to customers, identifying their needs, setting their expectations, and providing quality service after the sale to diverse customers. Also, our product is designed to be flexible with an adaptable architecture that allows it to meet lots of diverse needs. Furthermore, our product is designed with excellent security, which is especially important in the corporate verticals. Finally, our marketing people pitch me as a sort of boy genius to their corporate accounts because of my Ph.D. in MIS and Mathematics. This message plays very well and results in the potential corporate customers trusting us and the quality of our product.

Expanding into verticals other than higher education has challenges, however. If we have a fixed marketing budget, do you go to higher ed conferences or do you go to the corporate training route and try to break into that? Do we have enough gas in our tank to do both? Do we get big or go home?

Venturing into other market segments means selling to much more demanding customers. These markets will not tolerate paying premium prices for products that do not meet the deliverables promised or their expectations. Educational markets can be much less demanding. Educators are used to developing their own learning materials through fits and starts. The corporate customer wants products that are reliable and meet their expectations 'right out of the box.'

Table 1: Expenditures for Continuing Education for Selected Professions

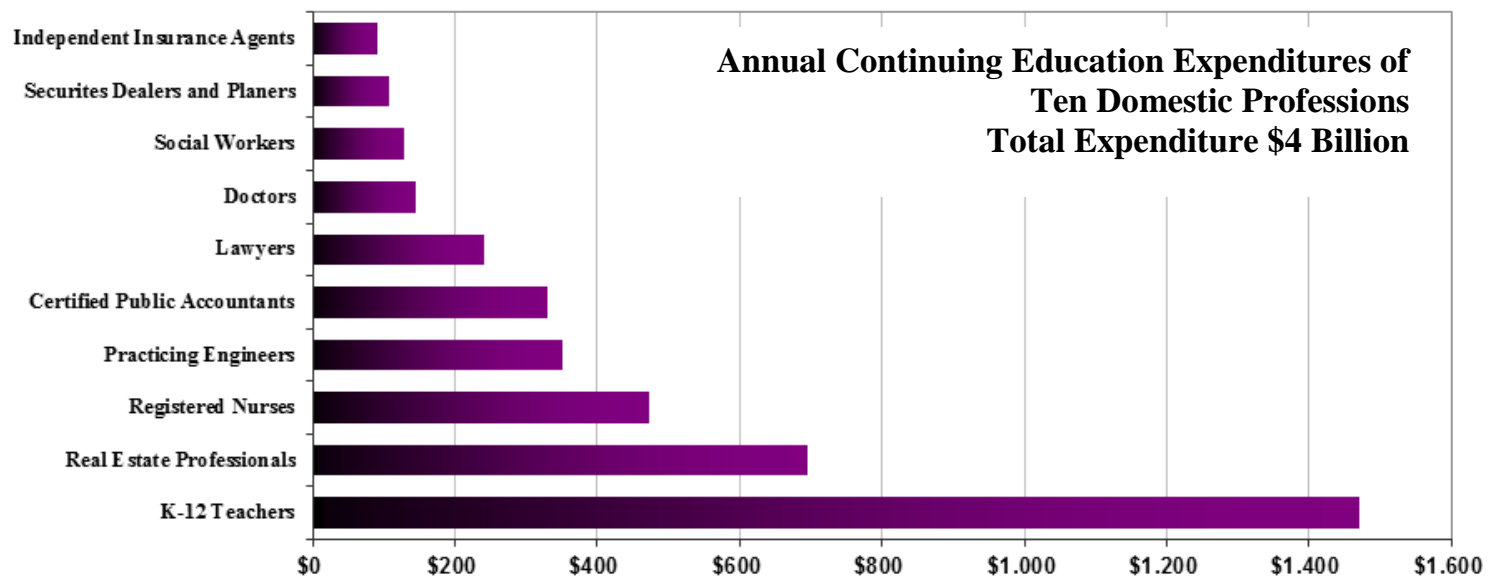

Source: Noble Systems graphic used in presentations to potential investors in 2001 . 
Furthermore, John, as a professor of management, said that he understood the needs of the college professor. He also understood the higher education market. He developed a product that was responsive to the needs of a professor. As John put it:

Higher education is a well-worn shirt that fits really well. As a professor, I live in the higher education market. My friends are potential customers. It is easy for me to understand a professor's needs. The depth of our knowledge of the other verticals is shallow. The potential customers in the other verticals speak a business language that is different from our language as mostly academics.

Another challenge for targeting other verticals is the relative small size of Noble when compared to its possible competitors. Few large corporations are comfortable dealing with small vendors. We try to deal with this problem by pretending to be bigger than we really are. We're like the lizard that puffs itself up to look bigger than it really is. We need to do this to attract bigger fish. Our small size also means that we are already understaffed in a growth environment.

Jack O'Brien pointed out that Noble System's relative small size also affected how they approached potential investors. For example, Jack said: "When potential investors come to our offices to check us out, we have to puff up to look good. We make sure everyone is in their offices working at their computers. I even had my niece sit at a computer pretending to work."

Selling to corporate verticals was also riskier than selling to higher education because universities don't go bankrupt or renege on their contracts while businesses do. For example, in one instance, Noble had a signed contract for $\$ 250,000$ that the corporation walked away from. Noble did not have the money to take them to court.

\section{VALUING NOBLE SYSTEMS}

One debate that the founders had was the value of the company. They had already turned down an offer of $\$ 10$ to $\$ 12$ million. In reflecting on that decision, Jack said:

At the present time in mid-2001, one controversial approach to valuing a business when P/E ratios cannot be used because earnings are negative uses the price-to-revenues ratio $(P / R)$ in place of the P/E ratio. In particular, to estimate the price (value) of a non-publicly traded company, some stock analysts use the average P/R ratio for publicly traded companies in an industry multiplied by the forecast earnings of the non-publicly traded company.

Tables 2 and 3 show the P/R ratios for some publicly traded companies in the business-to-business ecommerce industry and in the eLearning industry. The average $\mathrm{P} / \mathrm{R}$ ratio is used by some managers and investors to estimate the value of non-publicly traded companies, such as Noble Systems. Other stock market observers, however, suspect that the resulting valuations are wrong for most companies. The problem is that analysts don't know which companies will be losers and which companies will be superstars.

Table 2: E-Business Valuations

\begin{tabular}{|l|c|c|c|c|c|}
\hline \multicolumn{1}{|c|}{ Company } & Business Type & Symbol & $\begin{array}{c}\text { Valuation } \\
\text { May 16, 2000 }\end{array}$ & $\begin{array}{c}\text { Revenue } \\
\mathbf{1 9 9 9}\end{array}$ & Revenue Multiple \\
\hline Ariba & B to B & ARBA & $\$ 12.5 \mathrm{~b}$ & $\$ 45 \mathrm{~m}$ & $\mathbf{2 7 7}$ \\
\hline Commerce One & B to B & CMRC & $\$ 7 \mathrm{~b}$ & $\$ 35 \mathrm{~m}$ & $\mathbf{2 0 0}$ \\
\hline FirePond & B to B & FIRE & $\$ 610 \mathrm{~m}$ & $\$ 30 \mathrm{~m}$ & $\mathbf{2 0}$ \\
\hline Net Perception & B to B & NETP & $\$ 540 \mathrm{~m}$ & $\$ 15 \mathrm{~m}$ & $\mathbf{3 6}$ \\
\hline KANA & B to B & KANA & $\$ 2.77 \mathrm{~b}$ & $\$ 14 \mathrm{~m}$ & $\mathbf{1 9 7}$ \\
\hline Average & B to B & & & & $\mathbf{1 4 6}$ \\
\hline & & & & & $\mathbf{5 . 6}$ \\
\hline Click2Learn & e-Learning & CLKS & $\$ 210 \mathrm{~m}$ & $\$ 37 \mathrm{~m}$ & $\mathbf{1 0}$ \\
\hline e-College & e-Learning & ECLG & $\$ 61 \mathrm{~m}$ & $\$ 6 \mathrm{~m}$ & $\mathbf{5 8}$ \\
\hline Saba Software, Inc. & e- Learning & SABA & $\$ 642 \mathrm{~m}$ & $\$ 11 \mathrm{~m}$ & $\mathbf{1 3}$ \\
\hline Eloquent, Inc. & e- Learning & ELOQ & $\$ 170 \mathrm{~m}$ & $\$ 13 \mathrm{~m}$ & $\mathbf{2 2}$ \\
\hline Average & e-Learning & & & & \\
\hline
\end{tabular}

Source: Company records 2001. 
Table 3: eLearning Market Price-to-Sales Ratios - 2001

\begin{tabular}{|c|c|c|c|c|c|c|c|c|}
\hline \multicolumn{3}{|r|}{ FIRM } & \multicolumn{3}{|c|}{ PRIORITY } & \multicolumn{2}{|c|}{$\begin{array}{l}\text { CONSENSUS ESTIMATES } \\
\end{array}$} & \multirow[b]{2}{*}{$\begin{array}{l}\text { ACTUAL RECENT } \\
\text { FY REV \$1M }\end{array}$} \\
\hline NAME & TICK & Underwriters & SOFT & SERV & CONT & $\begin{array}{c}\text { 2001 REV } \\
\text { \$1M }\end{array}$ & 2001 EARN (LOSS) \$1M & \\
\hline DigitalThink, Inc. & DTHK & $\begin{array}{l}\text { Credit Suisse First Boston; Hambrecht \& } \\
\text { Quist; BancBoston Robertson Stephens }\end{array}$ & 2 & 3 & 1 & $\$ 38.7(\mathrm{~A})$ & $(\$ 9.20)$ & $\$ 38.70$ \\
\hline $\begin{array}{l}\text { Saba Software, } \\
\text { Inc. }\end{array}$ & SABA & $\begin{array}{l}\text { Goldman Sachs; Merrill Lynch; } \\
\text { FleetBoston; Banc of America }\end{array}$ & 1 & 3 & 2 & $\$ 53.0(\mathrm{~A})$ & $(\$ 8.10)$ & $\$ 53.00$ \\
\hline Docent, Inc. & DCNT & $\begin{array}{l}\text { Deutsche Banc Alex. Brown; Dain } \\
\text { Rauscher Wessels; Thomas Weisel } \\
\text { Partners }\end{array}$ & 1 & 3 & 2 & $\$ 42.00$ & $(\$ 34.70)$ & $\$ 11.00$ \\
\hline SkillSoft Corp & SKIL & & 3 & 2 & 1 & $\$ 19.3(\mathrm{~A})$ & $(\$ 9.20)$ & $\$ 19.30$ \\
\hline SmartForce plc & SMTF & & 3 & 2 & 1 & $\$ 260.00$ & $\$ 16.40$ & $\$ 168.10$ \\
\hline $\begin{array}{l}\text { Centra Software, } \\
\text { Inc. }\end{array}$ & CTRA & & 1 & 2 & 3 & $\$ 46.00$ & $(\$ 16.30)$ & $\$ 23.00$ \\
\hline click2learn & CLKS & & 1 & 2 & 3 & $\$ 51.00$ & $(\$ 11.20)$ & $\$ 42.50$ \\
\hline
\end{tabular}

Table 3: eLearning Market Price-to-Sales Ratios - 2001 (continued)

\begin{tabular}{|c|c|c|c|c|c|c|c|c|c|}
\hline FIRM & \multicolumn{3}{|c|}{ SHARE PRICE } & \multicolumn{3}{|c|}{ MARKET CAPITALIZATION \$1M } & \multicolumn{3}{|c|}{ PRICE TO SALES } \\
\hline NAME & RECENT & $\begin{array}{c}\text { 52-WK } \\
\text { HIGH }\end{array}$ & $\begin{array}{c}\text { 52-WK } \\
\text { LOW }\end{array}$ & RECENT & $\begin{array}{c}\text { 52-WK } \\
\text { HIGH }\end{array}$ & $\begin{array}{c}\text { 52-WK } \\
\text { LOW }\end{array}$ & RECENT & $\begin{array}{c}\text { 52-WK } \\
\text { HIGH }\end{array}$ & $\begin{array}{c}\text { 52-WK } \\
\text { LOW }\end{array}$ \\
\hline DigitalThink, Inc. & $\$ 13.11$ & $\$ 47.23$ & $\$ 5.34$ & $\$ 463$ & $\$ 1,667$ & $\$ 189$ & 9.8 & 35.2 & 4 \\
\hline Saba Software, Inc. & $\$ 9.60$ & $\$ 38.81$ & $\$ 3.56$ & $\$ 432$ & $\$ 1,746$ & $\$ 160$ & 8.1 & 32.9 & 3 \\
\hline Docent, Inc. & $\$ 4.69$ & $\$ 27.13$ & $\$ 2.75$ & $\$ 198$ & $\$ 1,148$ & $\$ 116$ & 8.1 & 46.8 & 4.7 \\
\hline \multicolumn{4}{|c|}{ PRINCIPAL COMP MEAN } & & & & 8.7 & 38.3 & 3.9 \\
\hline \multicolumn{4}{|c|}{ PRINCIPAL COMP MEDIAN } & & & & 8.1 & 35.2 & 4 \\
\hline SkillSoft Corp & $\$ 35.72$ & $\$ 38.94$ & $\$ 11.38$ & $\$ 564$ & $\$ 615$ & $\$ 180$ & 22 & 23.9 & 7 \\
\hline SmartForce plc & $\$ 36.10$ & $\$ 57.25$ & $\$ 18.13$ & $\$ 1,917$ & $\$ 3,040$ & $\$ 963$ & 8.3 & 13.2 & 4.2 \\
\hline Centra Software, Inc. & $\$ 11.90$ & $\$ 17.14$ & $\$ 2.75$ & $\$ 296$ & $\$ 427$ & $\$ 68$ & 9 & 12.9 & 2.1 \\
\hline click2learn & $\$ 2.89$ & $\$ 18.25$ & $\$ 1.00$ & $\$ 52$ & $\$ 330$ & $\$ 18$ & 1.2 & 7.4 & 0.4 \\
\hline
\end{tabular}

Source: Company records 2001. 
Table 4 shows Noble Systems's 10 year quarterly forecasted net cash flows based on three sets of assumptions made by Noble's senior managers: low (extremely pessimistic), middle, and high (extremely optimistic). In this table, Qtr 1 is the actual net cash flow from Quarter 1, 2001. The remainder of the quarterly cash flows are forecasts. Neither John nor Jack knew their actual cost of capital, but high yield corporate bonds averaged $12 \%$ in 2000 .

Table 4: Forecasted 10 Year Net Cash Flow for Noble Systems $(\$ 1000 s)$

\begin{tabular}{|c|c|c|c|}
\hline Time & Low & Middle & High \\
\hline $2001 \mathrm{Q} 1=\mathrm{Qtr} 1$ & -376 & -376 & -376 \\
\hline Qtr 2 & 380 & 341 & 223 \\
\hline Qtr 3 & -846 & -980 & -1078 \\
\hline Qtr 4 & -468 & -570 & -823 \\
\hline $2002 \mathrm{Q} 1=\mathrm{Qtr} 5$ & -1173 & -902 & -752 \\
\hline Qtr 6 & -1140 & -1345 & -753 \\
\hline Qtr 7 & 633 & 779 & 1002 \\
\hline Qtr 8 & -700 & -757 & -525 \\
\hline $2003 \mathrm{Q} 1=\mathrm{Q} \operatorname{tr} 9$ & -1186 & -984 & -695 \\
\hline Qtr 10 & -1393 & -1566 & -1512 \\
\hline Qtr 11 & 1163 & 1320 & 1704 \\
\hline Qtr 12 & -908 & -504 & -414 \\
\hline 2004 Q1 = Qtr 13 & -895 & -790 & -684 \\
\hline Qtr 14 & -1802 & -1574 & -1549 \\
\hline Qtr 15 & 819 & 938 & 1630 \\
\hline Qtr 16 & -935 & 938 & 907 \\
\hline 2005 Q1 = Qtr 17 & -1335 & -1755 & -927 \\
\hline Qtr 18 & -234 & -607 & 295 \\
\hline Qtr 19 & -763 & 923 & 1047 \\
\hline Qtr 20 & 962 & 707 & 776 \\
\hline 2006 Q1 = Qtr 21 & -1407 & 274 & 901 \\
\hline Qtr 22 & 703 & 188 & 961 \\
\hline Qtr 23 & -865 & 912 & 1873 \\
\hline Qtr 24 & 1510 & 998 & 1593 \\
\hline 2007 Q1 = Qtr 25 & -1758 & 1043 & 1662 \\
\hline Qtr 26 & 1673 & 1029 & 1696 \\
\hline Qtr 27 & -1019 & 1593 & 2704 \\
\hline Qtr 28 & 1548 & 1867 & 2579 \\
\hline 2008 Q1 = Qtr 29 & -1375 & 1456 & 2713 \\
\hline Qtr 30 & 1563 & 1633 & 2610 \\
\hline Qtr 31 & -507 & 2279 & 3804 \\
\hline Qtr 32 & 2091 & 2716 & 3620 \\
\hline 2009 Q1 = Qtr 33 & -875 & 2434 & 3626 \\
\hline Qtr 34 & 2359 & 2340 & 3703 \\
\hline Qtr 35 & -713 & 2910 & 5002 \\
\hline Qtr 36 & 2695 & 3245 & 4896 \\
\hline 2010 Q1 = Qtr 37 & -1030 & 2836 & 4812 \\
\hline Qtr 38 & 2378 & 3354 & 5265 \\
\hline Qtr 39 & -184 & 3965 & 6297 \\
\hline Qtr 40 & 2981 & 3949 & 5863 \\
\hline $2011 \mathrm{Q} 1=\mathrm{Qtr} 41$ & 5138 & 12572 & 21189 \\
\hline
\end{tabular}

Source: Company records as projected in Quarter 12001.

Tables 5 through 7 show the Income Statement, Balance Sheet, and Cash Flow Statement for Noble Systems. The source for all of these tables is the company records 2001. 
Table 5: Income Statement

Total Revenue

Total Operating Expense

Operating Income (EBIT)

Total Other Income (Expense)

Income Taxes

Net Income

19

$\$ 187$

$\$ 187,526$

755,281

$(567,755)$

3,794
1,760

$(632,899)$

760

224

200

\begin{tabular}{llll}
\hline$(\$ 563,961)$ & $(\$ 507,151)$ & $(\$ 632,339)$ & $(\$ 335,923)$ \\
\hline \hline
\end{tabular}

Table 6: Balance Sheet

\begin{tabular}{|c|c|c|c|c|}
\hline & 1998 & 1999 & 2000 & 1st half 2001 \\
\hline \multicolumn{5}{|l|}{ Assets } \\
\hline \multicolumn{5}{|l|}{ Current assets } \\
\hline Cash and cash equivalents & $\$ 2,861$ & $\$ 82,630$ & $\$ 6,847$ & $\$ 80,724$ \\
\hline Accounts receivable & 36,922 & 13,872 & 186,160 & $\$ 12,131$ \\
\hline Other receivables & - & - & - & $\$ 488$ \\
\hline Prepaid expenses & 11,197 & 4,091 & 12,974 & $\$ 4,760$ \\
\hline Total current assets & 50,980 & 100,593 & 205,981 & $\$ 98,102$ \\
\hline \multicolumn{5}{|l|}{ Property \& equipment } \\
\hline Total property \& equipment & 75,369 & 90,131 & 99,169 & $\$ 49,265$ \\
\hline Less accumulated depreciation & $(8,115)$ & $(24,307)$ & $(44,651)$ & $\$(30,453)$ \\
\hline Property \& equipment, net & 67,254 & 65,824 & 54,518 & $\$ 18,812$ \\
\hline \multicolumn{5}{|l|}{ Other assets } \\
\hline Deposits & 805 & 739 & 1,620 & $\$ 810$ \\
\hline Org costs, net of acc amortization. & 617 & 417 & 217 & $\$ 9$ \\
\hline Total other assets & 1,422 & 1,156 & 1,837 & $\$ 819$ \\
\hline Total assets & $\$ 119,656$ & $\$ 167,573$ & $\$ 262,336$ & $\$ 117,732$ \\
\hline \multicolumn{5}{|l|}{ Liabilities and shareholders' equity } \\
\hline \multicolumn{5}{|l|}{ Current liabilities } \\
\hline Notes payable & $\$ 20,000$ & $\$ 10,000$ & $\$-$ & $\$ 56,500$ \\
\hline Line of credit & - & - & 185,000 & $\$ 200,000$ \\
\hline Long-term debt, current portion & 6,304 & 7,274 & 7,888 & $\$ 1,021$ \\
\hline Salary payable, current portion & - & - & - & $\$ 14,748$ \\
\hline Accounts payable & 28,307 & 19,905 & 51,082 & $\$ 103,530$ \\
\hline Accrued severance & - & - & - & $\$ 91,467$ \\
\hline Accrued expenses & 8,132 & 114 & 308 & $\$ 7,884$ \\
\hline Deferred revenue & 43,736 & 31,246 & 73,325 & $\$ 17,081$ \\
\hline Total current liabilities & 106,479 & 68,539 & 317,603 & $\$ 492,231$ \\
\hline \multicolumn{5}{|l|}{ Long term liabilities } \\
\hline Long term debt, net of current portion & 14,838 & 7,846 & 2,042 & \\
\hline Salary payable, net of current portion & - & - & - & $\$ 47,610$ \\
\hline Total long term liabilities & 14,838 & 7,846 & 2,042 & $\$ 47,610$ \\
\hline Total liabilities & 121,317 & 76,385 & 319,645 & $\$ 539,841$ \\
\hline \multicolumn{5}{|l|}{ Shareholders' equity (deficit) } \\
\hline $\begin{array}{l}\text { Common stock, } 10 \mathrm{M} \text { shares authorized, } \$ .01 \\
\text { par value, } 2,288,333 \text { and 2,680,800 shares } \\
\text { issued and outstanding, respectively. }\end{array}$ & 16,883 & 22,883 & 26,808 & $\$ 131,687$ \\
\hline Additional paid-in capital & 663,616 & $1,257,616$ & $1,737,532$ & $\$ 1,037,983$ \\
\hline Retained deficit & $(682,160)$ & $(1,189,311)$ & $(1,821,650)$ & $\$(1,591,779)$ \\
\hline Total shareholders' equity (deficit) & $(1,661)$ & 91,188 & $(57,310)$ & $\$(422,109)$ \\
\hline $\begin{array}{l}\text { Total liabilities and shareholders' equity } \\
\text { (deficit) }\end{array}$ & $\$ 119,656$ & $\$ 167,573$ & $\$ 262,335$ & $\$ 117,732$ \\
\hline
\end{tabular}

Copyright by author(s); CC-BY 
Table 7: Cash Flow Statement

\begin{tabular}{|c|c|c|c|c|}
\hline & 1998 & 1999 & 2000 & 1st Half 2001 \\
\hline \multicolumn{5}{|l|}{ Cash flows from operating activities } \\
\hline Net Income (loss) & $\$(563,961)$ & $\$(507,151)$ & $\$(632,339)$ & $\$(335,923)$ \\
\hline \multicolumn{5}{|c|}{ Adjustments to reconcile net income (loss) to net cash } \\
\hline Depreciation & 7,508 & 16,192 & 20,345 & 10,672 \\
\hline Loss on equipment & - & - & - & 357 \\
\hline Amortization & 200 & 200 & 200 & 100 \\
\hline \multicolumn{5}{|l|}{ (Increase) decrease in operating assets } \\
\hline Accounts receivable & $(33,922)$ & 23,050 & $(172,288)$ & $(86,144)$ \\
\hline Other receivables & - & - & - & $(488)$ \\
\hline Prepaid expenses & $(10,712)$ & 7,106 & $(8,883)$ & 1,727 \\
\hline Deposits & $(264)$ & 66 & $(881)$ & - \\
\hline \multicolumn{5}{|l|}{ Increase (decrease) in operating liabilities } \\
\hline Accounts payable & 7,890 & $(8,402)$ & 92,518 & 115,487 \\
\hline Accrued severance & - & - & - & 91,467 \\
\hline Accrued expenses & 7,675 & $(8,018)$ & 194 & 7,730 \\
\hline Salary payable & - & - & - & 62,358 \\
\hline Deferred revenue & 41,336 & $(12,490)$ & 42,079 & $(19,582)$ \\
\hline Net cash used by operating activities & $(544,250)$ & $(489,447)$ & $(659,055)$ & $(330,176)$ \\
\hline \multicolumn{5}{|l|}{ Cash flows from investing activities } \\
\hline Purchase of equipment & $(64,680)$ & $(14,762)$ & $(9,038)$ & $(2,582)$ \\
\hline Net cash used by investing activities & $(64,680)$ & $(14,762)$ & $(9,038)$ & $(2,582)$ \\
\hline \multicolumn{5}{|l|}{ Cash flows from financing activities } \\
\hline Long-term debt & 21,142 & $(6,022)$ & $(5,190)$ & $(3,944)$ \\
\hline Line of credit & - & - & 185,000 & 107,500 \\
\hline Short term note & $(30,000)$ & 10,000 & - & 56,500 \\
\hline Stock issuance & 600,999 & 580,000 & 412,500 & 250,002 \\
\hline Net cash provided by financing activities & 592,141 & 583,978 & 592,310 & 410,058 \\
\hline Net increase (decrease) in cash & $(16,789)$ & 79,769 & $(75,783)$ & 77,301 \\
\hline Cash - beginning of the period & 19,650 & 2,861 & 82,630 & 3,424 \\
\hline Cash - end of the period & $\$ 2,861$ & $\$ 82,630$ & $\$ 6,847$ & $\$ 80,724$ \\
\hline
\end{tabular}

\section{CONCLUSION}

John Noble finished his explanation of Noble Systems at the same time that he finished the last gulp of beer that he drank with his dinner. After a long pause he said: "So what should we do?"

\section{AUTHOR INFORMATION}

Dr. Paul Schuman earned his Ph.D. at Cornell University in 1983. He is currently a professor of management at Minnesota State University, Mankato, where he teaches human resource management, strategic management, and business ethics. His research interests include human resource management ethics, e-learning, and job satisfaction, burnout, and turnover. E-mail: paul.schuman@mnsu.edu

Dr. Timothy Scott is currently a professor emeritus of management in the College of Business at Minnesota State University, Mankato. He is the co-author of a number of other simulations including Micromatic. His current research and publications are in the area of business ethics and using simulation games in teaching and training. He taught the undergraduate capstone course and MBA strategic management. Tim received his Ph.D. in Management from the University of Minnesota. E-mail: timothy.scott@ mnsu.edu

Dr. Jon Kalinowski earned his Ph.D. at the University of Iowa, Iowa City, in 1987. He is currently a professor of strategic management at Minnesota State University, Mankato. His teaching and research interests include strategic 
management, cross cultural differences in role conflict-ambiguity, life satisfaction and organizational commitment, and student/end-user satisfaction. E-mail: jon.kalinowski@ mnsu.edu (Corresponding author)

Dr. John Kaliski earned his Ph.D. in management information systems and mathematics from the University of Iowa and completed post-doctoral work at the University of Delft in the Netherlands. He is currently a professor of management in the College of Business at Minnesota State University, Mankato, teaching management information systems and entrepreneurship courses. He co-founded Anlon Systems, Inc. in late 1996 and served as Chief Technology Officer in the company. Dr. Kaliski is recognized as a pioneer in instructional information systems and has published and presented his research at EDUCASE, AACSB, Academy of Management, SIAM, Management Science, Mathematical Programming, and INFORMS. E-mail: john.kaliski@mnsu.edu

Dr. Claudia Pragman is a professor of management at Minnesota State University, Mankato, where she teaches operations management and statistics. She earned her Ph.D. from the University of Nebraska-Lincoln. Her research interests include learning and pedagogical scholarship, most notably in the areas of service learning and course redesign. E-mail: claudia.pragman@mnsu.edu 


\section{NOBLE SYSTEMS INC.: INSIDE THE MIND OF AN ENTREPRENEUR INSTRUCTOR'S MANUAL}

\section{Case Synopsis}

John Noble and Jack O'Brien, who both worked for a university, founded Noble Systems in 1995 as one of the original companies to develop and market eLearning systems for the higher education market. The company grew to 35-40 university accounts (including several of the largest university systems in the country), 12-15 employees, and revenues of $\$ 354,000$ in the first half of 2001. As Noble Systems grew, John and Jack faced many challenges: expenses exceeding revenues, cash flow problems, customer support difficulties, in-house management coordination problems, rapid technological change, emergence of strong competitors, a sales process to universities that was slow and frustrating, and a lack of partnerships with textbook publishers.

In the Summer of 2001, Noble Systems reached a critical decision point. The competitors in the higher education market developed better financing, marketing, and partnerships with textbook publishers, which Noble Systems had not been able to match. Noble Systems tested the waters outside of higher education by making a sale to a major insurance corporation to use Noble's eLearning system for corporate training. While corporate training markets were attractive for their huge sales potentials, John and Jack did not understand these markets as well as they understood higher education. Additional challenges of the corporate training market included more demanding customers and increased risks. The decision they faced in Summer 2001 was: Where would they get their future business? Higher education? Corporate training? Could they raise the capital to do both? Could they find partners? Should they sell the business?

\section{Time Frame of Case}

The decision-point in the case is set in Summer 2001. Is the case too old? Based on our class-testing of the case, we have found the age of the case to be one of its significant strengths for several related reasons.

In particular, the case is set near the peak of the dot-com bubble in a high-velocity market that was caught up in the bubble. As we have seen with the more recent bubble in real estate, the occurrence of market bubbles appears to be a regular occurrence that students need to learn to recognize and to analyze. Thus, cases that are set during bubbles provide students with experience in recognizing bubbles, in analyzing the situation, and in making recommendations to successfully manage during bubbles.

A problem, however, is that cases set during the most recent bubble are of limited value because many students will remember from their life experiences that the case is unfolding during a bubble. In our experiences, this recognition by students severely limits the learning value of the case. That is, if students easily realize that the case is occurring during a bubble because their memories of the bubble provide them with irresistible hindsight, then their recommendations will tend always to be to sell the business immediately to capitalize on the inflated business values during the bubble. In practice, without the benefit of hindsight, it is not easy always to recognize that one is in a bubble. By studying older bubbles, we have found that very few students, if any, remember the bubble, thus increasing the learning value of the case. Instead of relying on hindsight, students learn to recognize and to manage successfully in the volatile business situation as presented in the case.

Furthermore, the case is set shortly before the terrorist attacks of $9 / 11 / 2001$. The attacks had a significant effect on business, including the ability of small businesses to raise capital. The attacks had not been foreseen. Once again, we have found in class testing the case that sufficient time has now passed since the time of the case that few students, if any, realize that the case is unfolding immediately before an unforeseeable disaster because, while they remember 9/11, they don't remember in what year it occurred. Thus, instead of relying on hindsight, the age of the case allows students to focus on the high-velocity market situation as presented in the case.

\section{Courses and Levels for Which the Case is Intended}

The case and Instructor's Manual were written for undergraduate or MBA courses in strategic management. They can also be used in an entrepreneurship course if the instructor wishes to have a case that illustrates the 
strategic challenges associated with the decision whether to stay small and within the abilities of the founders, or to grow beyond their capabilities.

The case should be used as a capstone case later in the course because it requires the integration of business functions including financial analysis, marketing strategy, human resource strategy, appraisal of management performance, and possible changes in corporate strategy.

\section{Teaching Objectives}

Depending on the needs and preferences of the instructor, possible learning objectives for the case include:

1. Analyze a business situation in terms of its strengths, weaknesses, opportunities, and threats.

2. Appraise managerial performance.

3. Evaluate the financial condition of a business.

4. $\quad$ Evaluate the strategic human resource management of a business.

5. Evaluate the marketing strategy of a business and assess its market potentials.

6. Identify critical issues and problems.

7. Recommend courses of action to solve the critical issues and problems.

\section{Theory Application}

The case illustrates the challenges faced by typical start-up businesses. The company has never earned a profit. Losses are being covered by cash infusions by angel investors. While significant business opportunities are present, the company doesn't have the money to pursue them all. Essentially, the case involves problems of growth, vision, potential, and management.

The problems illustrated in the case can be analyzed using theories such as:

- $\quad$ SWOT Analysis

- $\quad$ Financial Analysis

- $\quad$ Business Valuation

- Strategic Human Resource Management

- $\quad$ Strategic Marketing

\section{Research Methods}

The information contained in the case was collected by interviewing the two co-founders of the company. The authors tape recorded and transcribed the interviews to serve as the basis for the case. Thus, the quotes contained in the case are real. The information provided in the exhibits was provided by the founders and are actual company data or reports.

While all of the data and other facts are real, the name of the company and the names of the people in the case have been disguised at their request.

One of the co-authors of this case was one of the co-founders of the company. The other co-authors are colleagues of this person.

\section{Suggested Teaching Approaches}

The case is well suited for both presentations and written assignments. During the previous four semesters, two of the co-authors have class-tested the case in a total of 10 sections of their strategic management classes at both the undergraduate and MBA levels. As a result of this class testing, we have revised the case and the Instructor's Manual. 
One possible approach that works well is to ask students for their analyses by asking a small number of broad questions, such as:

1. What is your evaluation of John Noble as a manager and leader? What grade would you give him as a leader and manager? What are John's objectives?

2. What problems does Noble face?

3. What alternatives does Noble have?

4. What are your recommendations? Your recommendations should be well supported with arguments and justifications.

The first three questions should be discussed in a single session of 50-75 minutes and the fourth question should then be discussed in a subsequent session of 20-30 minutes. Students are better able to develop and analyze recommendations after they've been exposed to a discussion that produces a common set of problems and alternatives. We have found that asking students to orally present their analyses and recommendations to the class has worked well.

\section{Discussion Questions and Answers}

1. What is your evaluation of John Noble as a manager and leader? What grade would you give him as a leader and manager? What are John's objectives?

Manager: John clearly has a strong technical background and was the brains behind the product. However, as he admits in the case, he was not skilled at the administrative skills beyond the management of the technology part of the product. However, his recognition of this fact does suggest he understands the importance of developing processes for customer service, product development, marketing, and financial management. The organization was clearly in need of depth in Human Resources and strategic direction. As a manager of the technical side of the business and product, John would likely receive an A.

Leader: The case does not provide a lot of information on the early challenges of generating the startup capital. However, the founders must have been successful in generating outside capital from investors or they would not have been able to challenge competitors for leadership in this developing market. The cash flow exhibit reveals that on a year to year basis they were able to generate funds to pay for expenses not covered by operations. As the case states, they were not successful in generating "strategic relationships" or the "deep pockets" of WebCt and Blackboard. The important point behind this question is to point out the difference between strategic management and the need for leadership versus a manager who focuses on operations, sales, and customer service type of issues. Jack's role was to be a leader in raising capital and in making high-level sales. John and Jack shared equally the leadership role in making strategic decisions. As a leader with strategic responsibility John would receive less than an A.

John's objective as stated in the case was “...become wealthy enough that I could walk away from technology and the rest of the world and build things — work with my hands and things like that." John and Jack turned down the offer of $\$ 10$ to $\$ 12$ million to sell the company. This suggests either that $\$ 10$ to $\$ 12$ million wasn't enough to meet their objectives given the ownership dilution from angel investors or that they lost sight of their objectives.

2. What problems does Noble Systems face?

To identify problems, students need to perform basic analyses to include: strategic analysis, SWOT analysis, financial analysis, strategic human resource management analysis, and marketing analysis.

a. Strategic analysis: What is Noble's current strategy? Which elements of their strategy are the strongest? Weakest? Does Noble's strategy provide a sustainable competitive advantage?

Currently, they are pursuing a best cost strategy. The case states that they provide the best product at a "moderate" or midrange price. Noble Systems is focused mostly on one particular market niche: higher 
education. In that market niche, Noble System's strategy is not to have the lowest price, but instead to have the lowest total cost of ownership while providing customers with a high quality product with the best product features. We don't think there is lot of utility in pushing whether they are best cost or differentiated. WebCt and Blackboard are probably going for the low cost position given their deep-pocket financing and strategic relationships.

Strongest elements of their strategy include a good understanding of the customers' needs, an outstanding product, and the technological skills to build the product. Once Carol Jackson was hired, Noble Systems' customer service and support also became a significant asset.

Their lack of size, strategic relationships, and lack of a large financial backer are significant weaknesses. Noble Systems' senior managers are in the process of reevaluating their strategic direction.

Their strategy in the educational market suggests they have the potential for a competitive advantage. The product is superior, does add value to customers, and probably is not durable because of the need to offer product upgrades and new versions. The owners made a strong case for the fact they had a sophisticated product that was well ahead of the competitors. The degree to which this product could be trumped by a new entrant is debatable. We would argue that with the pre-requisite internal processes and a flexible and scalable product, it would be difficult for a start-up to trump or leapfrog. Given the four criteria for competitive advantage, Noble appears to have a competitive advantage. However, Noble Systems has not shown that it can capitalize on this advantage.

Finally, Noble's orientation toward growth is reflected through the answering of three critical questions:

1. Should they expand, cut back, or continue their operations unchanged?

2. Should they concentrate activities with the current market or diversify into another or other industries?

3. Should they grow and expand nationally through internal development or external mergers, acquisitions, or strategic alliances?

The answer to these questions is usually composed of three general orientations called directional or grand strategies and includes growth, stability, or retrenchment. Their current strategy has been to concentrate on the educational market and emphasize horizontal growth through internal means. They are considering the advantages of moving to a different niche within the same market and continue with a concentration strategy through internal means because they have not been successful in attracting strategic alliances. Students will likely point this out through case discussion. They should also consider the viability of selling out as part of a retrenchment strategy. Stability does not appear to be feasible given how fast this market is moving and the problems Noble currently has with cash flow.

b. What does SWOT Analysis reveal about Noble's situation as of the end of the case?

\section{$\underline{\text { Strengths }}$}

- Understood the academic market well.

- Early entrant into the eLearning in higher education market.

- John's impressive background, knowledge, and technical talent.

- Superior product that is also flexible and adaptable to different customers.

- Lowest total cost of ownership.

- Achieved several large sales in academic market.

- Ability to attract angel investors to fund operations and growth.

- Good customer service once Carol was in place.

- Noble had an impressive array of nationally recognized reference accounts.

- John and Jack as strategic managers also have responsibilities for managing the human resources of the company, thus insuring congruence of HR and strategy. 
- Family corporate culture results in employee loyalty.

- Achieved one large sale in the corporate training market.

- Once a sale is made, it is difficult and costly to switch to a competing eLearning product.

\section{$\underline{\text { Weaknesses }}$}

- Overdependence on John for his knowledge and expertise - What if John is hit by a bus?

- Smaller than their competitors - potential customers are more comfortable dealing with bigger vendors.

- Company backed by unknown people - no recognizable names.

- Hard for a small business to keep up with exploding demand.

- Not enough employees - existing employees overworked.

- Lack of partnerships with educational content providers.

- Lack of formal human resource processes and procedures.

- Weak balance sheet and negative cash flow.

- Lack of capital required continual infusions by angel investors.

- Time spent raising capital diverted attention from sales and operations.

- Risk of running out of new angel investors.

- Lack of capital led to an inadequate marketing effort.

- Location in the Midwest was distant from other hi-tech businesses and from other universities and companies that would provide access to talent.

- Long and uncertain sales cycle in higher education market.

- Knowledge of the corporate training market is weaker than higher education.

- Hard to make a sale to an organization that is already using a competing eLearning system.

\section{$\underline{\text { Opportunities }}$}

- Stay focused on the one market they know best - higher education.

- Seek partnerships with educational content providers (professors and publishers).

- Seek partnerships with companies that provide corporate training and development.

- Raise their prices.

- Seek another buyer for the company.

- Pursue sales to other insurance companies to build on the one successful corporate training sale.

- Broaden sales efforts to other corporate training markets.

- Seek a merger partner in the eLearning industry.

- Pursue international markets.

- License Noble eLearning technology to competitors in the market.

- Noble can copy competitors' innovations.

- Add an up-front adoption service for large corporate accounts - take the customer's existing learning content and load it into the eLearning system for them.

\section{$\underline{\text { Threats }}$}

- Rapidly changing technology is hard to keep up with.

- Competitors have larger market shares and more employees.

- Competitors have deeper pockets.

- Competitors have partnerships with educational content providers.

- Competitors can copy product innovations.

- Increasing quality of competitors' products.

- Customers demand increased support, predictability, and quality.

- Unlike higher education, potential corporate training customers want the educational content already in the eLearning system. 
- Corporate training customers are more likely to renege on contracts than in higher education.

- Existing bigger competitors decide to pursue the corporate training market.

- Technical problems hurts the company's reputation (e.g., the server goes down).

- Consumer demand suddenly dries up because of a recession or some catastrophic event.

- Loss of a key employee.

- Overdependence on higher education - if higher education goes mostly with competing products, they've lost their key market.

Summary of SWOT analysis: Noble has an excellent product with depth in technical expertise, and good customer service. However, they have formidable threats and weaknesses reflected by a lack of strategic leadership, problems in HRM, and critical cash flow needs. These weaknesses suggest that they will have a difficult time taking advantage of future opportunities and adequately responding to threats.

c. Financial analysis: What is the assessment of Noble's financial strategy, financial performance, and financial condition?

Financial analysis should include:

1. Income statement: Calculate the Operating and Net Profit margins for 1998, 1999, 2000, and 2001. Calculate the growth in revenues from 98-99, 99-2000, 2000-2001 and CGR for 1998-2001. Calculate the growth rate each year for operating expenses and CGR for 1998-2001. (See below for the computations.)

- Operating Profit Margin: While very negative, the rate is improving or becoming less negative.

- Net Profit Margin: Same as Operating Profit Margin

- Revenue Growth: Strong growth in sales with year to year growth down in 1999-2000, but improving in 2000-2001.

- Growth in Expenses: The CGR of expenses is less than revenue growth, which is good. However, the stronger or increased growth in expenses from 1999-2000 and 2000-2001 is a large problem.

2. Balance Sheet: Calculate the Current Ratio for years 1998-2000. Calculate the Asset Turnover for 1998-2000. Calculate the debt to total assets for 1998-2000. (See Table 8 below for the computations.)

- Current Ratio: Highly variable and only 1999 is ok.

- Debt/Assets: Highly variable with 1999 showing a relatively high degree of debt. Given lack of profitability, any costs of debt are not being covered.

- Asset Turnover: This has improved from 1998, and is a positive.

Table 8: Calculation of Current Ratio, Debt to Total Assets and Asset Turnover

\begin{tabular}{|l|c|c|c|c|}
\hline \multicolumn{1}{|c|}{ Ratio/Year } & $\mathbf{1 9 9 8}$ & $\mathbf{1 9 9 9}$ & $\mathbf{2 0 0 0}$ & $\mathbf{2 0 0 1}$ \\
\hline Operating Profit Margin & $-302.7 \%$ & $-160.99 \%$ & $-141.7 \%$ & $-94.9 \%$ \\
\hline Net Profit Margin & $-300.7 \%$ & $-160.04 \%$ & $-141.5 \%$ & $-95.0 \%$ \\
\hline Current Ratio & .478 & 1.47 & .648 & .199 \\
\hline Debt/Assets & 1.01 & .46 & 1.22 & 4.58 \\
\hline Asset Turnover & 1.56 & 1.89 & 1.70 & 3.00 \\
\hline
\end{tabular}


3. Growth Rates:

- $\quad$ CGR of Sales $1998-2001=155 \%$

- $\quad$ CGR of Operating Expenses 1998-2001 = 122.2\%

- Year to year growth in sales: $1998-1999=68.5 \%, 1999-2000=41.3 \%, 2000-2001=58.4 \%$

- Year to year growth in operating expenses: $1998-1999=9.2 \%, 1999-2000=31 \%, 2000-2001=$ $27.8 \%$

\section{Evaluate the Cash flow statements:}

Note that while there is obviously strong negative cash flows (Table 7), they have been able to cover their cash flows with outside financing (angel investors). The obvious question is for how long will they be able to keep attracting the necessary angel investors.

Financial Conclusion: While the organization has shown positive signs in revenue growth, this is more than offset by the level and growth of operating expenses. The organizations current ratio/liquidity is a problem, especially the most recent year. The debt ratio has increased in 2001. Given the negative cash flows and profitability numbers, any additional debt becomes too much to cover. The asset turnover has improved, which is a positive. Overall, Noble Systems is in a very weak financial position that they've been able to cover so far with additional angel investors.

Discussion Note: Table 4 in the case shows that the company does not become consistently cash flow positive until Quarter 19 for the Middle and High scenarios. Thus, Noble would have to fund the cash shortages with further cash infusions until that time. Under the Middle scenario, Noble would need $\$ 8,359,008$. Under the High scenario, Noble would need $\$ 4,173,450$. These numbers were determined by summing the Quarters 3 through 18 net cash flow numbers that are in Table 4.

d. Strategic human resource management analysis: What kind of linkage is there between Noble's strategy and human resource management? What is your assessment of Noble's human resource management policies and procedures?

Most students will probably recognize that Noble Systems has been playing fast and loose with their human resource management as a problem. Students need to recognize that the solution is not to simply hire an HR expert and formalize the HR procedures. Instead, students should recognize the importance of linking HR and corporate strategy.

The best way to link an organization's strategy and human resource management is to use an integrative linkage in which the organization's senior HR executive is a full and integral member of the organization's strategic management team. By using integrative linkage, the senior HR executive is involved in both strategy formulation and strategy implementation. The senior HR executive brings to the strategic management team knowledge of the organization's human resource capabilities, including its strengths and weaknesses. The senior HR executive can also insure that the strategy being developed can be successfully implemented. Since the human resources of an organization typically constitute more than half of the organization's costs, such integrative linkage is critically important.

From the founding of Noble Systems until the hiring of Carol Jackson, the two founders and senior executives with primary strategic management responsibilities were John Noble and Jack O'Brien. These two senior executives were also responsible for managing the human resources within their respective areas of responsibility - John had responsibility for hiring and managing the technical employees and Jack had responsibility for hiring and managing the sales and marketing employees. Thus, until the hiring of Carol, Noble Systems used an integrative linkage of HR and strategy. 
However, John and Jack were novices at managing the growing human resources of the company. They also had little interest in doing so and they were both extremely busy with their other responsibilities. As a consequence, human resource management was largely on autopilot.

Furthermore, once Carol Jackson was hired to manage customer service and support, and to manage the day-to-day operations of the company, she began to have more responsibility for managing HR. However, Carol was not a senior manager; she did not serve on the company's strategic planning team. Thus, the company began to lose the linkage between HR and strategy.

In addition, while the company had hired a consultant to write an employee handbook, it is not clear that the company actually implemented the procedures in the handbook. As Jack notes in the case, they were still playing fast and loose with their HR, even though John notes that "Human resources were very important from a cost perspective - about $80 \%$ of our costs were labor costs."

As Noble Systems grows, they will eventually have to hire a senior HR executive who can implement appropriate HR policies and procedures. To recreate the desired integrative linkage, it will be important that the newly hired senior HR executive be a full member of the company's strategic planning team.

e. Marketing analysis: What is your assessment of Noble's marketing strategy?

Noble's current target market is primarily higher education. In this target market, Noble has achieved moderate success with many smaller accounts and with several large, nationally recognizable universities. Due to the length and complexity of making sales in the academic market, Noble has begun targeting the corporate training market in general, with an emphasis on professional certification training. While Noble has achieved one significant success in the corporate training market, it is too early to judge whether Noble will be successful in this new market.

Noble's marketing mix can be characterized in terms of the 4 P's (product, place, promotion, and price). In terms of their product and pricing, they generally follow a best cost strategy. Noble's product is highly regarded in the market, while the price for their product is set at an average range. Noble promotes its product primarily through personal selling, word-of-month advertising, and tradeshow booths. Compared to the competitors, Noble is woefully under-funded in its product promotion efforts. Noble's competitors aggressively promote their products through extensive advertising and a large, fully funded sales staff. The competitors attend multiple conferences annually with impressive presences at those conferences. Due to the high cost both of traditional advertising and of attending conferences, Noble's ability to effectively promote its products is severely curtailed. Noble's place of distribution was via the Internet.

Conclusion: What specific issues do John and Jack need to address?

There are several issues that students might wisely choose to put on John and Jack's worry list:

- How will they continue to attract the necessary capital to cover operating expenses?

- What should they do about pricing and the implementation of a best cost strategy?

- What market(s) should Noble Systems pursue or should they sell the business?

- How can they attract strategic partners?

- What should they do about their human resource issues?

3. What alternatives does Noble Systems have?

a. Spend resources to remain focused on the higher education market.

b. Spend resources to gain more customers in the corporate training market.

c. Try to do both (a) and (b).

d. Try to sell the business. 
4. What are your recommendations? Your recommendations should be well supported with arguments and justifications.

One of the reasons this case is interesting and useful is that there is no single best choice. Whatever alternative students choose to advocate, they should present a two-sided argument that brings out the pros and cons of their recommendation.

a. Spend resources to remain focused on the higher education market.

Pros:

- Remaining in a single niche allows focus.

- It is their expertise - they know this market well.

- They've been successful in this market.

Cons:

- Over-dependence on a single market.

- Slow and frustrating selling cycle because of diffused and uncertain decision-making authority.

- Strong competitors that have strategic partnerships and deeper pockets.

- Not as large a market as corporate training.

- Higher education market is growing slower than the corporate training market.

b. Spend resources to gain more customers in the corporate training market.

Pros:

- Solves over-dependence on relying on one market (higher ed).

- Greater market potential than higher ed.

- Leverage existing relationship in the insurance industry.

- Existing competitors don't have a presence in the corporate training market.

Cons:

- Need more capital to expand into additional markets.

- Lack of familiarity with the corporate training market.

- Competitors could leverage their size and partnerships to attack this market.

- Corporate training customers are more demanding.

- Corporate training is riskier because corporations are more likely to renege on contracts than institutions of higher education.

Students should use the existing sale to the insurance company to illustrate the revenue potential for the corporate training market.

The case states that Noble's potential revenues from this sale are a function of four things: (1) the number of member agents taking training that uses Noble's eLearning system, which is potentially as high as 300,000 ; (2) the number of credits taken per employee, which averages 15 credits per employee per year; (3) the price per credit, which typically is between $\$ 15$ and $\$ 50$; and (4) Noble's share of the gross revenue, which ranged between $20 \%$ and $30 \%$.

However, as noted by the case, the financial impact of this big sale depends on how quickly the insurance corporation implements the Noble eLearning system. Students will need to estimate the percentage of the 300,000 employees who will be converted to the Noble eLearning system. While the case does not provide 
a particular percentage, the case warns that the conversion will take an uncertain time for four reasons detailed in the case. There is no "right" answer. Each student's choice of the adoption percentage reflects the student's degree of optimism. The point that students should realize from this question is that the revenue potential depends critically on how fast the insurance company implements the Noble eLearning system, which is beyond Noble's effective control.

To illustrate the possibilities and the computations, we provide the following three examples:

1. Example of pessimistic case:

Number of employee $=300,000$

Number of credits per employee $=15$

Assume adoption percentage $=0.5 \%$ (low)

Assume price per credit $=\$ 15$ (low end of range)

Assume Noble's share of gross revenue $=20 \%$ (low end of range)

Annual revenue potential $=(300,000)(15)(.005)(\$ 15)(.20)=\$ 67,500$

2. Example of middle case:

Number of employee $=300,000$

Number of credits per employee $=15$

Assume adoption percentage $=2.0 \%$ (middle)

Assume price per credit $=\$ 32.50$ (middle of range)

Assume Noble's share of gross revenue $=25 \%$ (middle of range)

Annual revenue potential $=(300,000)(15)(.02)(\$ 32.50)(.25)=\$ 731,250$

3. Example of optimistic case:

Number of employee $=300,000$

Number of credits per employee $=15$

Assume adoption percentage $=10 \%$ (high)

Assume price per credit $=\$ 50$ (high end of range)

Assume Noble's share of gross revenue $=30 \%$ (high end of range)

Annual revenue potential $=(300,000)(15)(.10)(\$ 50)(.30)=\$ 6,750,000$

c. Try to do both (a) and (b).

Pros:

- Leverage existing success in higher education and in insurance to expand into other corporate training markets.

- Large market potential.

- Reduces risk by spreading into additional markets.

Cons:

- Requires more capital than (a) and (b) alone.

- Requires difficult choices in how to allocate scarce resources among the markets.

- Loss of focus.

- Noble managers and employees are already over-worked. 
Discussion points: The evaluation of alternatives (a), (b), and (c) depends on how will they continue to attract the necessary capital to cover operating expenses? Noble has been successful raising the necessary capital to cover its most recent operating expenses. However, the stakes are increasing as competitors are spending heavily on marketing and leveraging strategic relationships. They will need to develop an attractive business plan for the corporate market and it is really questionable given their current burn rate of cash whether they will be able to cover operating expenses long enough to shop a business plan for the corporate market. Even if they stay in the education market they will be challenged to generate the necessary capital to survive.

Students should recognize the company's poor financial condition. As a result, students should also recognize that there are not currently enough resources to pursue both markets, which is choice (c). This doesn't mean that they can't operate in both markets; it means that their current limited discretionary marketing money won't stretch across both markets. They have to choose one or the other market unless they can successfully find new investors willing to put up the capital for the risky proposition of pursing both markets. The riskiness of pursuing the corporate training market is compounded by their limited knowledge and experience in this market. Furthermore, as John Noble points out in the case, the corporate training buyer is much more demanding than the higher education buyer.

If they pursue the corporate training market, which would be "crossing the chasm," they will need to not only get a very large cash infusion but develop the internal critical mass to understand a variety of different markets and their training needs. They will not be able to play as fast and loose with their corporate training customers as they have played with their higher education customers.

For any of the alternatives (a), (b), or (c), they will need to:

1. Improve their Human Resource Function. (See Question 2, Part D.)

2. Formalize the Marketing effort and develop a clearer strategy for this function. (See Question 2, Part E.)

3. Generate more certain financing. (See Question 2, Part C.)

4. Secure partnerships. Finding a partner is like finding a spouse. As the case describes, many of the education content providers have already committed to partnerships with competing eLearning companies. Finding an uncommitted partner that would be compatible with Noble Systems is likely to be a challenge.

d. Try to sell the business.

Selling the company obviously depends on finding someone who is willing to make an acceptable offer.

Students should use the information presented in the case to estimate the possible valuation of Noble Systems.

The valuation of Noble Systems can be estimated by at least two methods. The first method is to use the Price/Revenue (P/R) ratios. The P/R ratios were commonly used in 2001 to estimate the value of nonpublicly traded technology companies, although many analysts questioned the wisdom of doing so. Despite these concerns, one could follow the practice of the time and use the average P/R ratio of publicly traded technology companies as the basis for the estimation. Tables 2 and 3 in the case show the relevant $P / R$ ratios.

In Table 2, the most relevant comparison group is the eLearning companies. The mean $\mathrm{P} / \mathrm{R}$ ratio of the four eLearning companies is 21.65 . However, the mean is greatly influenced by Saba's outlying ratio. If Saba is excluded, the mean P/R ratio of the remaining three companies is 9.53 . If we use a $P / R$ ratio of 10 as the appropriate estimate of the P/R ratio for Noble, then the estimated valuation of Noble in 2000 would be their actual revenues of $\$ 446,731$ (from Table 5) multiplied by 10 , which equals $\$ 4,467,310$. If we estimate Noble's 2001 annual revenue by doubling the revenue from the first half of 2001, then the estimated valuation of Noble would be $\$ 353,912$ times 2 times 10 , which equals $\$ 7,078,240$. 
Table 3 shows directly that the mean $\mathrm{P} / \mathrm{R}$ ratio among the three principle competitors is 8.7 , while the median is 8.1 . Table 4 also directly shows that the overall mean $\mathrm{P} / \mathrm{R}$ ratio is 6.4 , while the overall median is 8.1. However, the exhibit also directly shows that there is substantial variation in the $\mathrm{P} / \mathrm{R}$ ratios among the publicly traded companies, from a low $\mathrm{P} / \mathrm{R}$ of 0.2 , to a high of 23.9.

If we use a $\mathrm{P} / \mathrm{R}$ ratio of 0.02 as an estimate of the lowest possible $\mathrm{P} / \mathrm{R}$ ratio for Noble, and if we use Noble's actual 2000 revenues of $\$ 446,731$, then the estimated valuation of Noble is $\$ 446,731$ multiplied by 0.2 , which equals $\$ 89,346.20$. As before, if we estimate Noble's 2001 revenues, then the estimated valuation is $\$ 353,912$ times 2 times 0.2 , which equals $\$ 141,564.80$.

If we use a P/R ratio of 23.9 as an estimate of the highest possible $\mathrm{P} / \mathrm{R}$ ratio for Noble, then the estimated valuation of Noble in 2000 is $\$ 446,731$ times 23.9 , which equals $\$ 10,676,870.90$. For 2001, the estimated valuation of Noble is $\$ 353,912$ times 2 times 23.9 , which equals $\$ 16,916,993.60$.

Thus, based on the P/R ratio, the valuation of Noble Systems is estimated to be between about $\$ 89,000$ and \$17 million.

While the use of $\mathrm{P} / \mathrm{R}$ ratios was common in 2001, financial analysts questioned its appropriateness. A more appropriate method is to estimate the company's future cash flows, discount the future cash flows estimates to present values, and then add up the total of the present values.

Table 4 in the case presents Noble's estimates of their future net cash flows over the 10 year period beginning in Quarter 1 2001. As noted in the case, the managers produced three sets of forecasts: low (extremely pessimistic), middle, and high (extremely optimistic). The table below shows the present value of each cash flow, as well as the cumulative cash flow numbers. The table uses a discount rate of $12 \%$, which is based on the statement in the case that "Neither John nor Jack knew their actual cost of capital, but high yield corporate bonds averaged $12 \%$ in 2000 ":

Table 9: Forecasted 10 Year Net Cash Flow for Noble Systems with Present Values and Cumulative Present Values (\$1000s)

\begin{tabular}{|l|c|c|c|c|c|c|c|c|c|}
\hline Time & Low & Middle & High & PV Low & $\begin{array}{c}\text { Cum PV } \\
\text { Low }\end{array}$ & PV Middle & $\begin{array}{c}\text { Cum PV } \\
\text { Middle }\end{array}$ & PV High & $\begin{array}{c}\text { Cum PV } \\
\text { High }\end{array}$ \\
\hline Qtr 1 & -376 & -376 & -376 & -365 & -365 & -365 & -365 & -365 & -365 \\
\hline Qtr 2 & 380 & 341 & 223 & 359 & -7 & 321 & -44 & 210 & -155 \\
\hline Qtr 3 & -846 & -980 & -1078 & -774 & -781 & -897 & -942 & -986 & -1142 \\
\hline Qtr 4 & -468 & -570 & -823 & -416 & -1196 & -506 & -1448 & -731 & -1873 \\
\hline Qtr 5 & -1173 & -902 & -752 & -1012 & -2208 & -778 & -2226 & -648 & -2521 \\
\hline Qtr 6 & -1140 & -1345 & -753 & -955 & -3163 & -1126 & -3353 & -630 & -3151 \\
\hline Qtr 7 & 633 & 779 & 1002 & 515 & -2648 & 634 & -2719 & 815 & -2337 \\
\hline Qtr 8 & -700 & -757 & -525 & -553 & -3200 & -598 & -3317 & -414 & -2751 \\
\hline Qtr 9 & -1186 & -984 & -695 & -909 & -4109 & -754 & -4071 & -533 & -3284 \\
\hline Qtr 10 & -1393 & -1566 & -1512 & -1036 & -5146 & -1165 & -5236 & -1125 & -4409 \\
\hline Qtr 11 & 1163 & 1320 & 1704 & 840 & -4305 & 954 & -4283 & 1231 & -3179 \\
\hline Qtr 12 & -908 & -504 & -414 & -637 & -4942 & -353 & -4636 & -290 & -3469 \\
\hline Qtr 13 & -895 & -790 & -684 & -610 & -5552 & -538 & -5174 & -466 & -3935 \\
\hline Qtr 14 & -1802 & -1574 & -1549 & -1191 & -6743 & -1040 & -6214 & -1024 & -4959 \\
\hline Qtr 15 & 819 & 938 & 1630 & 526 & -6217 & 602 & -5612 & 1046 & -3913 \\
\hline Qtr 16 & -935 & 938 & 907 & -583 & -6800 & 584 & -5028 & 565 & -3347 \\
\hline Qtr 17 & -1335 & -1755 & -927 & -807 & -7607 & -1062 & -6090 & -561 & -3908 \\
\hline Qtr 18 & -234 & -607 & 295 & -137 & -7744 & -357 & -6446 & 174 & -3735 \\
\hline Qtr 19 & -763 & 923 & 1047 & -435 & -8180 & 526 & -5920 & 597 & -3138 \\
\hline Qtr 20 & 962 & 707 & 776 & 533 & -7647 & 391 & -5528 & 430 & -2708 \\
\hline Qtr 21 & -1407 & 274 & 901 & -756 & -8403 & 147 & -5381 & 484 & -2224 \\
\hline Qtr 22 & 703 & 188 & 961 & 367 & -8037 & 98 & -5283 & 502 & -1722 \\
\hline Qtr 23 & -865 & 912 & 1873 & -438 & -8475 & 462 & -4821 & 949 & -773 \\
\hline Qtr 24 & 1510 & 998 & 1593 & 743 & -7732 & 491 & -4330 & 784 & 11 \\
\hline Con
\end{tabular}


Table 9 cont.

\begin{tabular}{|l|c|c|c|c|c|c|c|c|c|}
\hline Qtr 25 & -1758 & 1043 & 1662 & -840 & -8572 & 498 & -3832 & 794 & 804 \\
\hline Qtr 26 & 1673 & 1029 & 1696 & 776 & -7796 & 477 & -3355 & 787 & 1591 \\
\hline Qtr 27 & -1019 & 1593 & 2704 & -459 & -8255 & 717 & -2638 & 1218 & 2809 \\
\hline Qtr 28 & 1548 & 1867 & 2579 & 677 & -7578 & 816 & -1822 & 1127 & 3936 \\
\hline Qtr 29 & -1375 & 1456 & 2713 & -583 & -8161 & 618 & -1204 & 1151 & 5087 \\
\hline Qtr 30 & 1563 & 1633 & 2610 & 644 & -7518 & 673 & -531 & 1075 & 6162 \\
\hline Qtr 31 & -507 & 2279 & 3804 & -203 & -7721 & 912 & 380 & 1521 & 7684 \\
\hline Qtr 32 & 2091 & 2716 & 3620 & 812 & -6909 & 1055 & 1435 & 1406 & 9089 \\
\hline Qtr 33 & -875 & 2434 & 3626 & -330 & -7239 & 918 & 2353 & 1367 & 10456 \\
\hline Qtr 34 & 2359 & 2340 & 3703 & 864 & -6375 & 857 & 3209 & 1355 & 11812 \\
\hline Qtr 35 & -713 & 2910 & 5002 & -253 & -6628 & 1034 & 4244 & 1778 & 13590 \\
\hline Qtr 36 & 2695 & 3245 & 4896 & 930 & -5698 & 1120 & 5363 & 1689 & 15279 \\
\hline Qtr 37 & -1030 & 2836 & 4812 & -345 & -6043 & 950 & 6313 & 1612 & 16891 \\
\hline Qtr 38 & 2378 & 3354 & 5265 & 773 & -5270 & 1091 & 7404 & 1712 & 18603 \\
\hline Qtr 39 & -184 & 3965 & 6297 & -58 & -5328 & 1252 & 8656 & 1988 & 20591 \\
\hline Qtr 40 & 2981 & 3949 & 5863 & 914 & -4414 & 1211 & 9867 & 1797 & 22389 \\
\hline Qtr 41 & 5138 & 12572 & 21189 & 1529 & -2885 & 3742 & 13609 & 6306 & 28695 \\
\hline
\end{tabular}

The table above shows that under the most pessimistic assumptions, the valuation of Noble is $\$-2,885,180.43$. Under the middle set of assumptions, the valuation of Noble is $\$ 13,608,702.05$. Finally, under the most optimistic assumptions, the valuation of Noble is $\$ 28,695,264.80$.

In other words, looking at the forecast cash flows, Noble can be valued somewhere between zero and \$29 million. As noted previously, using the P/R ratios, Noble can be valued somewhere between $\$ 89,346$ and $\$ 17$ million.

While these are wide ranges of possible valuations, they bracket the price that Noble has already been offered and declined of $\$ 10$ to $\$ 12$ million. In making the decision to decline this offer, Noble's managers were looking at the potential future valuations that are possible from the more optimistic scenarios. That is, to sell the business for more than $\$ 10$ to $\$ 12$ million will require finding an optimistic buyer who believes reality will turn out to exceed the middle scenario of $\$ 13.6$ million.

Students should be pressed as to why their chosen recommendation is better than the alternatives.

\section{Epilogue}

Shortly after the time period of this case, Noble experienced a series of significant changes. The external events of the 9/11 attacks and the collapse of the ".com" bubble had a significant, negative impact on the eLearning industry in general and on Noble in particular. The chaos of these events had the effects of:

- $\quad$ delaying sales that were already in the pipeline and

- $\quad$ making private equity funds more difficult to secure.

In response to these changes, Noble dramatically reduced its monthly expenses by over $60 \%$, primarily through staffing reductions and the elimination of all discretionary expenditures. Noble was able to secure a large private angel investor which, coupled with the reduction in expenses, was able to stabilize the company's cash position.

While maintaining its higher education market base, Noble Systems decided to pursue the corporate training market in earnest. As part of this strategic shift, a series of changes in upper management were made; the most significant of these changes included the hiring of a new Chief Executive Officer with extensive corporate education experience. 
The corporate education strategy yielded limited success. Several small accounts were secured in the software, manufacturing, and health care education markets. The insurance vertical grew more slowly than was first projected.

In the Summer of 2003, Noble Systems was sold to a better-financed competitor in the eLearning market. After a brief transition period, all of the principal employees mentioned in this case moved on to other opportunities. At the time this case was written, Noble's products were still being used by some of Noble's larger reference accounts. 